\title{
Analysis of Speed Related Behavior of Kuwaiti Drivers Using the Driver Behavior Questionnaire
}

\author{
Jamal Al Matawaha ${ }^{1 *}$, Khair Jadaan², Brian Freeman³ \\ ${ }^{1}$ Civil Engineering Department, College of Technological Studies, Kuwait (PAAET), P.O. Box 23167 Safat 13092, Kuwait \\ 2 Civil Engineering Department, The University of Jordan, Amman, 11942, Jordan \\ ${ }^{3}$ School of Engineering, University of Guelph, Guelph, Ontario, N1G 2W1, Canada \\ *Corresponding author, e-mail: jamaln1@hotmail.com
}

Received: 19 September 2018, Accepted: 08 October 2018, Published online: 23 May 2019

\begin{abstract}
The Manchester Driver Behaviour Questionnaire (DBQ) is widely used to measure driving styles and investigate the relationship between driving behaviour and accidents involvement. Recent evaluations of different population groups have taken place throughout the world, including countries in the Arabian Gulf. This study seeks to extend the application of the DBQ to Kuwait with its mix of native and expatriate drivers, by examining the relationships between speed-related behavior and accident involvement using a speed-related score (SRS). For this purpose, 536 respondents (425 Kuwaitis and 111 Non-Kuwaitis) were asked to complete a questionnaire based on the DBQ parameters as well as background information. The results showed that young Kuwaiti male drivers scored highest in most of the areas. Factor analysis resulted in four significant dimensions; speed-related violations, anger related violations, errors, and lapses. The study focused on the speed related violation score (SRS) as the dependent variable. The statistical analysis using ANOVA and t- test showed that there is a significant effect of such factors as accident involvement, age, gender, nationality, education level, driving experience and marital status. Some countermeasures to reduce accidents were identified focusing on those groups with higher SRS values.
\end{abstract}

Keywords

DBQ, Kuwait, driver behavior, traffic safety, speeding

\section{Introduction}

A growing number of motorists reported being exposed to aggressive, violent and/or reckless behaviors on public roads. These behaviors constitute a major concern given the evidence that demonstrates a link between aggressive driving violations and increases in the risk of accident involvement (Dobson et al., 1999; Parker et al., 1995; Reason et al., 1990; Underwood et al., 1999). As a result, a significant amount of research focuses on identifying the causes and the subsequent impact of these behaviors on road safety.

Road traffic accidents represent the third largest cause of death in Kuwait (Wang and Naghavi, 2016) and driving related accidents result in over 500 fatalities per year in Kuwait (KUNA, 2016).

Accidents and accident likelihood have been studied by many researchers with root causes attributed to individual driving styles and driving habits. The Manchester Driver Behavior Questionnaire (DBQ) was developed to measure individual concepts and types of driver behavior. It has been applied in various developed and developing countries. This study, takes the matter further and aims to measure various types of driver behavior in Kuwait using the same technique, i.e. the DBQ.

\section{Overview of previous research}

The DBQ measures how often drivers experience three categories defined as lapses, errors, and violations. Lapses are drivers' actions that are usually considered not to be life-threatening. Errors were defined by Reason et al., (1990) as constituting a failure of planned action and include failures in observation and misjudgments. Violations are typical of aggressive behavior driving, which were defined by Reason et al., (1990) as actions that were deliberate deviations from practices considered to be important to maintain safety in a potentially hazardous environment.

Many researchers have used the DBQ to measure driver behavior in different countries including Britain (Reason et al., 1990), Qatar and the United Arab Emirates (Bener et al., 2008), Canada (Cordazzo et al., 2014), Denmark 
(Martinussen et al., 2013), France (Guého et al., 2014), Finland and the Netherlands (Lajunen et al., 2004), Australia (Stephens and Fitzharris, 2016), and Turkey (Sümer, 2003).

The questionnaire addressed lapses by asking such questions as how often they operated the wrong switch, took the wrong lane approaching roundabouts or junctions, misread signs on exiting roundabouts, or reached a wrong destination. As for errors, respondents asked questions such as how often they failed to see a 'Stop' or 'Give Way' sign, or failed to observe cyclists and pedestrians crossing side roads.

Questions for violations included how often drivers disregarded the speed limits late at night or very early in the morning, crossed a junction knowing that the traffic lights were changing, showed hostility to another road user, or expressed anger verbally. (Reason et al., 1990). Lawton et al. (1997) categorized violations according to motivational interpersonal aggression ('aggressive violation') and deliberate deviation ('ordinary violations'). On the other hand, Lajunen and Parker (2001) and Lajunen et al. (1998) stated that violation items are sometimes difficult to differentiate, because of local conditions, such as snow on the road (Scandinavia) or larger number of cyclists (Holland).

The literature referred above showed that culture plays a part in determining driver behavior. It noted variations in the categories of lapses, errors, and violations that reflect true cultural differences. Traffic cultures may vary at the regional level. The DBQ item "brake too quickly on slippery road" has very different meanings in countries with a long snowy winter than in countries where snow tires are never required. Traffic environment and culture play a major role. For example, a striking difference in Muslim culture is that alcohol is not commonly consumed or recreational drugs widely used, thus reducing the possibility of encountering a driver under the influence of alcohol or drugs. Furthermore, the percentage of expatriate drivers residing in the Gulf States are often very high compared to the national drivers. In Kuwait, approximately $70 \%$ of the total population of 4.4 million in 2016 were expatriates. (Public Authority of Civil Information, 2017).

\section{Materials and method}

\subsection{The questionnaire}

The questionnaire used in this study consists of six sections (parts). The first section consists of general demographic information such as age, sex, nationality, occupation, and education level. The second section includes driving characteristics data such as distances traveled, driving experience, and seatbelt usage. The third section dealt with accidents information such as history, types, severity and causation. The fourth section included a total of 26 questions on driver behavior and the related factors categorized as Violations, Errors, and Lapses. The questions were further classified according to various aspects such lake of attention speeding, overtaking as detailed in Appendix The fifth section on driving strengths and weakness as far as driving performance is concerned. This section included 20 questions related to the dangerous driving situations and reactions. The sixth section explores Road Safety Strategies with questions related to specific remedial measures such as road design and law enforcement, and road safety campaigns. The fifth and sixth section, as well as anger related violations, errors, and lapses, will be used for future research. We only focus on speed related violations in the fourth section see Table 1.

\subsection{Data collection}

A pilot survey of 50 questionnaires was randomly distributed to drivers in Kuwait during November 2016 to identify any potential problems in the questionnaire design. The main survey was carried out between 3 December 2016 to 15 May 2017 when 700 questionnaires were distributed to a random sample of drivers at various locations in Kuwait. Of the returned responses, 164 questionnaires were rejected, either because they were incomplete or because the answers were considered unrealistic, leading to an overall response rate of $76 \%$.

A total number of 536 Kuwaiti and non-Kuwaiti male and female drivers took part in the study and were included in the statistical analysis. All participants had driving licenses and filled out the Driver Behavior Questionnaire (DBQ) and items related to drivers' driving records and demographic variables.

Participants were asked several questions including those that indicate their age, gender, marital status, educational level, occupation, place of living, housing conditions, driving experience, type of car, frequency of seatbelt use, reasons for not wearing seat belt, speed choice on different roads, annual mileage, traffic offences, history of accident and injury involvement.

\subsection{Measures}

The responses to the 26 questions related to the driver behavior were taken on a six-point Likert Scale $(0=$ never, $1=$ hardly ever, 2 = occasionally, 3 = quite often, $4=$ frequently, and $5=$ nearly all the time). The participants were asked to indicate how often they committed each behavior in the previous years. 
Table 1 The mean, frequency and percentage of each speed related question

\begin{tabular}{|c|c|c|c|c|c|c|c|c|c|c|}
\hline & \multicolumn{2}{|l|}{ VIOLATIONS (speed related) } & \multirow{2}{*}{ Never } & \multirow{2}{*}{$\begin{array}{c}1 \\
\begin{array}{c}\text { Hardly } \\
\text { ever }\end{array}\end{array}$} & \multirow{2}{*}{$\begin{array}{c}2 \\
\begin{array}{c}\text { Occasio- } \\
\text { nally }\end{array}\end{array}$} & \multirow{2}{*}{$\begin{array}{c}3 \\
\begin{array}{l}\text { Quite } \\
\text { often }\end{array}\end{array}$} & \multirow{2}{*}{$\begin{array}{c}4 \\
\begin{array}{c}\text { Frequ- } \\
\text { ently }\end{array}\end{array}$} & \multirow{2}{*}{$\begin{array}{c}5 \\
\text { Nearly } \\
\text { all the } \\
\text { time }\end{array}$} & & \multirow[t]{2}{*}{ Mean } \\
\hline & & & & & & & & & Total & \\
\hline V1 & $\begin{array}{l}\text { Drive especially close to the car in front as a signal } \\
\text { to its driver to go faster or get out of the way }\end{array}$ & $\begin{array}{l}\text { Perc. } \\
\text { Freq.. }\end{array}$ & $\begin{array}{c}18 \% \\
99\end{array}$ & $\begin{array}{c}19 \% \\
102\end{array}$ & $\begin{array}{c}18 \% \\
97\end{array}$ & $\begin{array}{c}22 \% \\
120\end{array}$ & $\begin{array}{c}10 \% \\
58\end{array}$ & $\begin{array}{c}11 \% \\
60\end{array}$ & $\begin{array}{c}100 \% \\
536\end{array}$ & 2.22 \\
\hline $\mathrm{V} 2$ & $\begin{array}{l}\text { Cross a junction knowing that the traffic lights have } \\
\text { already turned red }\end{array}$ & $\begin{array}{l}\text { Perc. } \\
\text { Freq.. }\end{array}$ & $\begin{array}{c}52 \% \\
283\end{array}$ & $\begin{array}{c}22 \% \\
121\end{array}$ & $\begin{array}{c}12 \% \\
69\end{array}$ & $\begin{array}{c}6 \% \\
32\end{array}$ & $\begin{array}{c}3.4 \% \\
18\end{array}$ & $\begin{array}{c}2.4 \% \\
13\end{array}$ & $\begin{array}{c}100 \% \\
536\end{array}$ & 0.92 \\
\hline V3 & $\begin{array}{l}\text { Disregard the speed limits late at night or early in } \\
\text { the morning }\end{array}$ & $\begin{array}{l}\text { Perc. } \\
\text { Freq.. }\end{array}$ & $\begin{array}{c}25 \% \\
135\end{array}$ & $\begin{array}{c}17 \% \\
93\end{array}$ & $\begin{array}{c}18 \% \\
99\end{array}$ & $\begin{array}{c}17 \% \\
92\end{array}$ & $\begin{array}{c}12 \% \\
69\end{array}$ & $\begin{array}{c}9 \% \\
48\end{array}$ & $\begin{array}{l}100 \% \\
536\end{array}$ & 2.02 \\
\hline V4 & Disregard the speed limits on a motorway & $\begin{array}{l}\text { Perc. } \\
\text { Freq.. }\end{array}$ & $\begin{array}{c}19 \% \\
106\end{array}$ & $\begin{array}{c}19 \% \\
103\end{array}$ & $\begin{array}{c}22 \% \\
123\end{array}$ & $\begin{array}{c}17 \% \\
93\end{array}$ & $\begin{array}{c}11 \% \\
64\end{array}$ & $\begin{array}{c}8.8 \% \\
47\end{array}$ & $\begin{array}{c}100 \% \\
536\end{array}$ & 2.09 \\
\hline V6 & $\begin{array}{l}\text { Become impatient with a slow driver in the outer } \\
\text { lane and overtake on the inside (right) lane }\end{array}$ & $\begin{array}{l}\text { Perc. } \\
\text { Freq.. }\end{array}$ & $\begin{array}{c}7.1 \% \\
38\end{array}$ & $\begin{array}{c}11 \% \\
64\end{array}$ & $\begin{array}{c}13 \% \\
72\end{array}$ & $\begin{array}{c}24 \% \\
133\end{array}$ & $\begin{array}{c}20 \% \\
110\end{array}$ & $\begin{array}{c}22 \% \\
119\end{array}$ & $\begin{array}{c}100 \% \\
536\end{array}$ & 3.06 \\
\hline V7 & $\begin{array}{l}\text { Get involved with unofficial 'races' with other } \\
\text { drivers }\end{array}$ & $\begin{array}{l}\text { Perc. } \\
\text { Freq.. }\end{array}$ & $\begin{array}{c}57 \% \\
308\end{array}$ & $\begin{array}{c}21 \% \\
116\end{array}$ & $\begin{array}{c}10 \% \\
54\end{array}$ & $\begin{array}{l}5.4 \% \\
29\end{array}$ & $\begin{array}{c}3.4 \% \\
18\end{array}$ & $\begin{array}{c}2.1 \% \\
11\end{array}$ & $\begin{array}{l}100 \% \\
536\end{array}$ & 0.82 \\
\hline V10 & $\begin{array}{l}\text { Stay in a motorway lane that you know will be } \\
\text { closed ahead until the last minute before } \\
\text { forcing your way into the other lane. }\end{array}$ & $\begin{array}{l}\text { Perc. } \\
\text { Freq.. }\end{array}$ & $\begin{array}{c}22 \% \\
122\end{array}$ & $\begin{array}{c}22 \% \\
122\end{array}$ & $\begin{array}{c}18 \% \\
97\end{array}$ & $\begin{array}{c}20 \% \\
107\end{array}$ & $\begin{array}{c}9.7 \% \\
52\end{array}$ & $\begin{array}{c}6.7 \% \\
36\end{array}$ & $\begin{array}{c}100 \% \\
536\end{array}$ & 1.91 \\
\hline
\end{tabular}

\section{Analysis of data}

\subsection{Characteristics of respondents}

Analysis of the collected data showed a response rate from Kuwaiti drivers higher than from non-Kuwaiti drivers $(79.5 \%$ and $20.5 \%$, respectively). Table 2 shows the demographic characteristics of the respondents It can be seen that the overwhelming majority being males (74\%) and Kuwaiti nationals (nearly $80 \%$ ). Over half of the participants held a bachelor's degree or higher and a similar percentage were married.

The age distribution of the participants ranged from 18 to 72 years with the mean age of 31.8 years. The high proportion of the age group $18-24$ of $42 \%$ is driven by the survey given to respondents near colleges and universities.

Annual kilometers, representing the total distances traveled, between less than $5,000 \mathrm{~km}$ and more than $40,000 \mathrm{~km}$ were grouped into $5,000 \mathrm{~km}$ intervals with the highest percentage of drivers driving between 10,000 and $15,000 \mathrm{~km}$ (21\%). Table 3 shows the frequency distribution of the annual average kilometers driven. The analysis of data revealed that males and females annually drive $21,768 \mathrm{~km}$ and $13,964 \mathrm{~km}$ respectively with an average of $19,730 \mathrm{~km}$. This shows that men are driving around $61 \%$ more than the distances traveled by the females.

\subsection{Characteristics and causes of accidents}

The participants reported their involvement in a total of 380 accidents with 305 (80.3\%) Property Damage Only accidents, 74 (19.4\%) injury accidents and only one fatal accident. $71 \%$ of the survey participants reported that they
Table 2 Demographic characteristics of the respondents

\begin{tabular}{lc}
\hline Gender & $74 \%$ \\
\hline Male & $26 \%$ \\
Female & \\
\hline Education level & $17.9 \%$ \\
\hline High school or below & $27.2 \%$ \\
Diploma & $42.4 \%$ \\
Bachelor's degree & $12.5 \%$ \\
Postgraduate & \\
\hline Marital status & $49.1 \%$ \\
\hline Married & $50.9 \%$ \\
Unmarried & \\
\hline Nationality & $79.5 \%$ \\
\hline Kuwaiti & $20.5 \%$ \\
\hline Non-Kuwait & $17.9 \%$ \\
\hline Age group & $42 \%$ \\
\hline $18-24$ & $13.5 \%$ \\
\hline $30-39$ & $17.1 \%$ \\
\hline 50 \& above & \\
\hline & \\
\hline & \\
\hline & \\
\hline
\end{tabular}

have been involved in one or more accidents during their driving experience, while $29 \%$ had not. The accidents' severity are summarized in Table 4.

The respondents were asked about the causes of accidents. The results in Table 5 show that speeding, defined as driving over the posted speed limit, is identified as a single cause of about one third of total accident. If combined with carelessness, they cause almost half of the 
Table 3 Frequency distribution of annual average kilometres driven

\begin{tabular}{lcc}
\hline Kilometres & Frequency & Percent \\
\hline$<5,000$ & 33 & $6.2 \%$ \\
$5,000-10,000$ & 101 & $18.8 \%$ \\
$10,000-15,000$ & 112 & $20.9 \%$ \\
$15,000-20,000$ & 56 & $10.4 \%$ \\
$20,000-25,000$ & 63 & $11.8 \%$ \\
$25,000-30,000$ & 56 & $10.4 \%$ \\
$30,000-35,000$ & 35 & $6.5 \%$ \\
$35,000-40,000$ & 28 & $5.2 \%$ \\
$>40,000$ & 52 & $9.7 \%$ \\
\hline Total & 536 & $100.0 \%$ \\
\hline
\end{tabular}

Table 4 Accident severity

\begin{tabular}{lcc}
\hline Accident severity & Frequency & Percent \\
\hline PDO & 305 & $80.3 \%$ \\
Injury & 74 & $19.4 \%$ \\
Fatality & 1 & $0.3 \%$ \\
\hline Total & 380 & $100 \%$ \\
\hline
\end{tabular}

Table 5 Accident causes

\begin{tabular}{lcc}
\hline Accident factors & Frequency & Percent \\
\hline General Violations & 130 & $34.2 \%$ \\
Speeding & 123 & $32.4 \%$ \\
Carelessness & 62 & $16.3 \%$ \\
Other & 60 & $15.8 \%$ \\
Alcoholic involved & 5 & $1.3 \%$ \\
\hline Total & 380 & $100 \%$ \\
\hline
\end{tabular}

accidents. These results gives an indication of the general attitude and behavior of drivers. Accidents involving alcohol were found to be the cause of only $1.3 \%$ of the total. It should be noted, however, that Kuwait is an Islamic country that prohibits importing, selling and consuming alcoholic beverages.

\subsection{Violations}

The respondents were asked if they ever had general violation tickets such as running a red-light, speeding, or parking. The results of the analysis are summarized in Table 6 which shows that speeding was found to be the most common type of violations among drivers in Kuwait with $37.6 \%$ of the total number of violations followed by parking. Speeding and parking are the most common offences in Kuwait (Central Statistics Bureau, 2017).
Table 6 Reported violations

\begin{tabular}{lcc}
\hline Violation Type & Frequency & Percent \\
\hline Over Speed(Speeding) & 157 & $37.6 \%$ \\
Parking & 129 & $30.9 \%$ \\
Red-light & 44 & $10.5 \%$ \\
Parking and Over Speed & 28 & $6.7 \%$ \\
Red-light and Over Speed & 26 & $6.2 \%$ \\
Red-light, parking and Over Speed & 24 & $5.7 \%$ \\
Red-light and parking & 7 & $1.7 \%$ \\
Others & 3 & $0.7 \%$ \\
\hline Total & 418 & $100 \%$ \\
\hline
\end{tabular}

Table 7 Drivers' activities while driving

\begin{tabular}{lcc}
\hline Type of Activity & Frequency & Percent \\
\hline Using mobile phone & 229 & $55.6 \%$ \\
Other activities & 83 & $20.1 \%$ \\
Smoking & 45 & $10.9 \%$ \\
Children in front & 34 & $8.3 \%$ \\
Folding legs & 16 & $3.9 \%$ \\
Reading newspaper & 3 & $0.7 \%$ \\
Drinking alcohol & 2 & $0.5 \%$ \\
\hline Total & 412 & $100 \%$ \\
\hline
\end{tabular}

\subsection{Activities while driving}

The respondents were asked about what activities that they engage in while driving. The results in Table 7 show that respondents often use their mobile phones while driving (55.6\%), despite knowing that it is illegal to do so (Kuwait Ministry of Interior, 2014). Again, drinking alcohol shows the least activity (only $0.5 \%$ ) as it is prohibited by religion and difficult to obtain locally.

\subsection{Seat belt usage}

Only $40.7 \%$ of the respondents said they regularly use seat belts while $43.7 \%$ said they occasionally used them. A small group (15.7\%) reported, not using seat belts at all. The reasons behind those not using seatbelts and those who use them occasionally are shown in Table 8 . It can be seen that over $40 \%$ of drivers do not use the seat belt mainly because they do not feel comfortable wearing them, and not because they are aware of its resulting in safe driving.

\section{Statistical analysis}

\subsection{Reliability analysis}

A lower bound reliability estimate was computed for each category (Violations, Errors, and Lapses) separately using 
Table 8 Reasons for not using seat belts

\begin{tabular}{lcc}
\hline Reason & Frequency & Percent \\
\hline Discomfort & 90 & $28.9 \%$ \\
Forget to use & 79 & $25.4 \%$ \\
Inconvenience & 53 & $17.1 \%$ \\
Combination of reasons & 26 & $8.4 \%$ \\
Fear of being trapped & 19 & $6.1 \%$ \\
Other reasons & 18 & $5.8 \%$ \\
Interfered with clothes & 15 & $4.8 \%$ \\
Not Necessary & 11 & $3.5 \%$ \\
Total & 311 & $100 \%$ \\
\hline
\end{tabular}

Cronbach's $\alpha$, a commonly used statistic for estimating the reliability of test scores (Warrens, 2014). The $\alpha$ of each category was calculated using SPSS software and represents the average covariance between item-pairs and variance of the total score and given by Eq. (1):

$\alpha=\frac{N^{*} \bar{c}}{\sigma^{2}+((N-1) * \bar{c})}$

where $N$ is the number of item-pair being compared, $\bar{c}$ is the average covariance between item pairs, and $\sigma^{2}$ is the average variance.

Results in Table 9 show a good range of reliability between variables, which may reflect redundant or duplicate questions (Streiner, 2003).

This research focuses on the violation part, which consist of 10 questions in the questionnaire survey. Seven of these questions are speed related violation and 3 questions are anger related violation. The statistical analysis will focus on speed related violation. The average of these 7 question are calculated to evaluate each individual participant and is referred to as Speed Related Score (SRS).

\subsection{Relationship between speed-related behavior score and affecting factors}

The overall speed related score was introduced as a dependent variable in order to evaluate the effect of various contributing factors which were used as independent variables. The studied factors include age, gender, education level, marital status, nationality, and driving experience. An overall speed related score (SRS) was calculated as an average of the 7 questions for each driver (V1, V2, V3, V4, V6, V7, and V10) see Table 1. The t-test was used to compare significant differences in overall speed related scores between two independent groups (such as Gender, Marital Status, and Nationality). When the analysis involved three

\begin{tabular}{lc}
\multicolumn{2}{l}{ Table 9 Reliability analysis using Cronbach's $\alpha$} \\
\hline Item-pair & $\alpha$ \\
\hline Violation & 0.867 \\
Errors & 0.817 \\
Lapses & 0.847 \\
\hline
\end{tabular}

or more groups, such as Age, Education Level, and Driver Experience, the one-way ANOVA technique was used. In both the t-test and one-way ANOVA, the level of significance was set at the $95 \%$ confidence interval level $(\mathrm{p}<$ 0.05). Follow-up tests were conducted to evaluate pair wise differences among the means. The post hoc comparisons were conducted using Dunnett's C test.

The above analysis was carried out to test the following hypotheses:

1. Age: young driver have more aggressive driving on the road (higher SRS ) than older driver

2. Education Level: the lower the level of education the more aggressive driving (higher SRS ) on the road

3. Experience: the less experienced drivers would have more aggressive driving behavior (higher SRS) than more experienced drivers

4. Gender: male drivers have more aggressive driving behavior on the road (higher SRS) than female drivers.

5. Nationality: Kuwaiti drivers have more aggressive driving behavior (higher SRS) than non-Kuwaiti drivers.

6. Marital Status: drivers who were single had more aggressive driving behavior (higher SRS) than drivers who were married.

7. Prior Accident or Accident involvement: drivers who were involved in one or more accidents, had more aggressive driving behavior (higher SRS) than drivers who were not involved in accidents

The drivers of age group 18-24 showed the highest speed-related behavior (mean $=2.48$ ), whereas the drivers of age group 50-above showed the lowest aggressive behavior $($ mean $=0.88$ ) as shown in Table 10 .

The results of the one-way ANOVA supported the above age hypothesis. This is expected as young drivers, are more likely to underestimate the probability of specific risks caused by traffic situations (Brown and Gorger, 1988; Deery, 1999) and they overestimate their own driving skills (Moe, 1986).

Regarding the education level, the results showed significant differences in the means between the various groups. 
Table 10 ANOVA results for SRS.

\begin{tabular}{|c|c|c|c|c|c|c|c|c|c|}
\hline Age Group & $\mathrm{N}$ & Mean & SD & $18-24$ & $25-29$ & $30-39$ & $40-49$ & $\mathrm{~F}$ & sig \\
\hline $18-24$ & 225 & 2.48 & 0.89 & & & & & 55.465 & 0.000 \\
\hline $25-29$ & 72 & 1.82 & 1.02 & $*$ & & & & & \\
\hline $30-39$ & 92 & 1.57 & 1.11 & $*$ & NS & & & & \\
\hline $40-49$ & 85 & 1.29 & 0.76 & $*$ & * & NS & & & \\
\hline 50-above & 62 & 0.88 & 0.61 & $*$ & $*$ & $*$ & $*$ & & \\
\hline Education level & $\mathrm{N}$ & Mean & $\mathrm{SD}$ & $\begin{array}{l}\text { Up to High } \\
\text { school }\end{array}$ & Diploma & Bachelor & & $\mathrm{F}$ & sig \\
\hline Up to High school & 96 & 2.11 & 1.15 & & & & & 20.136 & 0.000 \\
\hline Diploma & 146 & 2.21 & 0.98 & NS & & & & & \\
\hline Bachelor & 227 & 1.74 & 1.04 & $*$ & * & & & & \\
\hline Postgraduate & 67 & 1.13 & 0.81 & $*$ & $*$ & * & & & \\
\hline Groups & $\mathrm{N}$ & M & SD & $\begin{array}{c}\text { Less Than } \\
2 \text { years }\end{array}$ & $2-5$ years & $5-10$ years & & $\mathrm{F}$ & sig \\
\hline Less than 2 years & 60 & 2.12 & 0.92 & & & & & 43.118 & 0.000 \\
\hline $2-5$ years & 156 & 2.22 & 0.94 & NS & & & & & \\
\hline $5-10$ years & 93 & 1.74 & 1.11 & NS & $*$ & & & & \\
\hline More than 10 years & 227 & 1.14 & 0.94 & $*$ & $*$ & $*$ & & & \\
\hline
\end{tabular}

The drivers with Diploma (two years college) showed the highest aggressive behavior (mean $=2.21$ ), whereas the Postgraduate drivers showed the lowest aggressive behavior $($ mean $=1.13)$

As far as driving experience is concerned, the results shown in Table 10 reveal that here were no significant differences in the means between the groups (less than 2 years, 2-5years), (less than 2 years, 5-10 years), but there are significant differences in the means between the groups more than 10 years and all other groups.

A t-test was conducted to evaluate the rest of the hypotheses and the results are shown in Table 11. The results clearly support the above-stated hypotheses that are related to gender, nationality, marital status and accident history.

Male drivers on average were found to have more aggressive driving behavior than female drivers. This agrees with the results of research carried out elsewhere such as that of Laapotti et al. (2003), which evaluated driver attitudes towards road safety in Finland

Kuwaiti drivers were found to be more aggressive than non-Kuwaiti drivers and single had more aggressive driving behavior than drivers who were married. The results of the t-test shown in Table 11also support the hypothesis that drivers with one or more accident showed more aggressive behavior compared to drivers with no accidents.
Table 11 Results of t-tests for SRS.

\begin{tabular}{|c|c|c|c|c|c|}
\hline Gender & $\mathrm{N}$ & Mean & $\begin{array}{c}\text { Std. } \\
\text { Deviation }\end{array}$ & $\mathrm{T}$ & Sig \\
\hline Male & 396 & 1.9402 & 1.09899 & 3.015 & 0.003 \\
\hline Female & 140 & 1.6393 & 0.98366 & & \\
\hline Nationality & $\mathrm{N}$ & Mean & $\begin{array}{c}\text { Std. } \\
\text { Deviation }\end{array}$ & $\mathrm{T}$ & Sig \\
\hline $\mathrm{Ku}$ & 426 & 2.0556 & 1.03820 & 8.77 & 0.000 \\
\hline Non-Ku & 110 & 1.1100 & 0.88130 & & \\
\hline marital status & $\mathrm{N}$ & Mean & $\begin{array}{c}\text { Std. } \\
\text { Deviation }\end{array}$ & $\mathrm{T}$ & Sig \\
\hline Single & 263 & 2.277 & 0.96431 & 9.466 & 0.000 \\
\hline Married & 273 & 1.461 & 1.029 & & \\
\hline $\begin{array}{l}\text { Accident } \\
\text { involved }\end{array}$ & $\mathrm{N}$ & Mean & $\begin{array}{c}\text { Std. } \\
\text { Deviation }\end{array}$ & $\mathrm{T}$ & Sig \\
\hline Yes & 380 & 1.9516 & 1.07849 & 3.082 & 0.002 \\
\hline No & 156 & 1.6423 & 1.04579 & & \\
\hline
\end{tabular}

*Significant $(\mathrm{p}<0.05)$

\section{Discussion}

The previous section reveal that speed related score is more influenced by demographic factors such as age, gender, Nationalities and accident involvement than other DBQ factors anger related, errors and lapses. Although the results of the statistical analysis supported the given hypotheses, it should be noted that the sample contains are 
more young drivers up to high school and Diploma than the other education levels $(70.6 \%$ of drivers in the age group 18-24 are 'up to high school' and Diploma level). There is also more young single drivers than married drivers in the sample (89\% of drivers in the age group 18-24 were single). Married drivers are assumed to have more concerns, possibly due to family responsibilities

One further explanation of the results is that there are more young Kuwaiti drivers than young non-Kuwaiti drivers in the country's population. Several possible reasons exist that explain why non-Kuwaitis are less aggressive while driving. Expatriate drivers tend to have lower financial status than Kuwaitis and are often responsible for paying the fines if they receive thus try to avoid such unnecessary fines and expenses.

Kuwaiti law requires a bachelor's degree for non-Kuwaiti private drivers (Kuwait News Agency, 2014). Lastly, expatriate drivers often do not have the same influence, (or WASTA meaning influencing bodies), within the traffic department that allows some Kuwaitis to avoid paying fines.

The study has an important limitation in that the result of accident involvement in this research was based on self-reporting. Thus, the verification of the accuracy of the questionnaire responses might in some cases be difficult. Some respondents might not remember the exact number of accidents in which they had been involved. Also, it is difficult to obtain responses from a representative cross-section of the target population, i.e. representative samples.

\section{Conclusions}

Speed and violations play important roles in accident occurrence, especially for young Kuwaiti drivers, who were found to be more aggressive in driving, since they do not pay much attention to enforcement.

Based on the results of this research, age has the highest impact on driver behavior including speed. Young male drivers appear to be more aggressive and more likely to be involved in accidents than other subgroups. This result is

\section{References}

Bener, T., Ozkan, T., Lajunen, T. (2008) "The driver behaviour questionnaire in Arab Gulf countries: Qatar and United Arab Emirates", Accident Analysis \& Prevention, 40(4), pp. 1411-1417. https://doi.org/10.1016/j.aap.2008.03.003

Brown, I. D., Groeger, J. A. (1988) "Risk perception and decision taking during the transition between novice and experienced driverstatus", Ergonomics, 31(4), pp. 585-597. https://doi.org/10.1080/00140138808966701 consistent with other studies that identify younger drivers as accident risks (de Winter and Dodou, 2010).

Among DBQ factors this study focused on studying speed-related factor through using a speed-related score (SRS). The results revealed that younger drivers have higher SRS than mature driver, male have higher score than female, Kuwaiti drivers have higher score than non-Kuwaits and single drivers have higher score than married drivers. In addition, the overall high SRS has higher accident involvement.

It appears that overall DBQ score in Kuwait is higher than the DBQ score in Qatar and U.A.E, whereas the DBQ score in Qatar and U.A.E. is higher than European countries (Bener et al., 2008 ) Furthermore, the results of the study revealed that fines on Kuwaiti drivers violating traffic regulations are ineffective.

The countermeasures applied successfully in European countries. Thus, in order to reduce driver's accident involvement, the countermeasures should be implemented effectively in Kuwait. These countermeasures mainly include higher traffic law enforcement levels as well as traffic education and training supported with traffic campaign.

Practically, the results of this research imply that further studies should be conducted to identify areas for improving lower education drivers, targeting certain segments of the population for extra training in safe road usage. There is an implied need for further education and training of young, unmarried drivers, either through the media or driving schools to increase their feeling of responsibility and improve their hazard perception.

\section{Acknowledgements}

This research was partially funded by the Public Authority for Applied Education and Technology. We are grateful for the support received from the Kuwait Traffic Safety Society in helping to distribute the survey.

Central Statistic Bureau (2017) "Statistics of transportation" [online] Available at: https://www.csb.gov.kw/Socan Statistic EN.aspx?ID=41 [Accessed: 18 January 2018]

Cordazzo, S. T., Scialfa, C. T., Bubric, K., Ross R. J. (2014) "The driver behavior questionnaire: A North American analysis", Journal of Safety Research, 50, pp. 99-107, 2014.

https://doi.org/10.1016/j.jsr.2014.05.002 
Deery, H. A. (1999) "Hazard and risk perception among young novice drivers", Journal of Safety Research, 30(4), pp. 225-236. https://doi.org/10.1016/S0022-4375(99)00018-3

de Winter, J., Dodou, D. (2010) "The driver behaviour questionnaire as a predictor of accidents: A meta-analysis", Journal of SafetyResearch, 41(6), pp. 463-470, 2010. https://doi.org/10.1016/j.jsr.2010.10.007

Dobson, A., Brown, W., Ball, J., Powers, J., McFadden, M. (1999) "Women drivers' behaviour, socio-demographic characteristics and accidents", Accident Analysis and Prevention, 31(5) pp. 525-535. https://doi.org/10.1016/S0001-4575(99)00009-3

Grayson, G. B., Saxton, B. F. (2002) "The development of hazard perception testing", Transport Research Laboratory, Report no. 558.

Guého, L. Granie, M. A., Abric. J. C. (2014) "French validation of a new version of the driver behavior questionnaire (DBQ) for drivers ofall ages and level of experiences", Accident Analysis \& Prevention, 63, pp. 41-48. https://doi.org/10.1016/j.aap.2013.10.024

KUNA (2016) "Nearly 500 people a year die in Kuwait traffic accidents - Smart phone use a main cause of accidents", Kuwait Times, [online] Available at: http://news.kuwaittimes.net/website/nearly-500-people-year-die-kuwait-traffic-accidents [Accessed: 17 September 2018]

Kuwait Ministry of Interior. Maj.Gen. Abdul-Fattah Al-Ali (2014) "The start of the traffic campaigns for the mobile devices and seat belt violators in 15 February - 04/02/2014", [online] Available at: https://moi.gov.kw/portal/venglish/ShowPage.aspx?newsID=3619. [Accessed: 24 March 2018]

Kuwait News Agency (2014) "New conditions imposed on driving licenses for expats license linked to iqama validity minimum salary of kd 600 needed", [online] Available at: https://news.kuwaittimes.net/new-conditions-imposed-driving-licenses-expats-license-linked-iqama-validity-minimum-salary-kd-600-needed/. [Accessed: 24 March 2018]

Laapotti, S., Keskinen, E., Rajalin, S. (2003) "Comparison of young male and female drivers attitude and self-reported traffic behaviour in Finland in 1978 and 2001", Journal of Safety Research, 34(5), pp. $579-587$ https://doi.org/10.1016/j.jsr.2003.05.007

Lajunen, T., Parker, D., Summala, H. (2004) "The manchester driver behavior questionnaire: a cross-cultural study", Accident Analysis \& Prevention, 36 (2), pp. 231-238. https://doi.org/10.1016/S0001-4575(02)00152-5

Lajunen, T., Parker, D. (2001) "Are aggressive people aggressive drivers? A study of the relationship between self-reported general aggressiveness, driver anger and aggressive driving", Accident Analysis and Prevention, 33(2), pp. 243-255. https://doi.org/10.1016/S0001-4575(00)00039-7

Lajunen, T., Parker, D., Stradling, S. (1998) "Dimensions of driver anger, aggressive and highway code violations and their mediation by safety orientation in UK drivers", Transportation Research, Part F: Traffic Psichology and Behaviour, 1(2), pp. 107-121. https://doi.org/10.1016/S1369-8478(98)00009-6
Lawton, R., Parker, D., Manstead, A. S. R., Stradling S. G. (1997) "The role of affect in predicting social behaviours: The case of road traffic violations", Journal of Applied Social Psychology, 27(14), pp. 1258-1276. https://doi.org/10.1111/j.1559-1816.1997.tb01805.x

Martinussen, L. M., Hakamies-Blomqvist, L., Moller, M., Ozkan, T., Lajunen, T. (2013) "Age, gender, mileage and the DBQ: The validity of the driver behavior questionnaire in different driver groups", Accident Analysis \& Prevention, 52(28), pp. 228-236. https://doi.org/10.1016/j.aap.2012.12.036

Moe, D. (1986) "ORIGINAL TITLE" (Young drivers. Relation between perceived and real ability. Behavioural studies) (report STF63 A92002), Trondheim: SINTEF Samferdselsteknikk (in Norwegian)

Parker, D., West, R., Stradling, S., Manstead, A. S. R. (1995) "Behavioral characteristics and involvement in different types of trafficaccident", Accident Analysis and Prevention, 27(4), pp. 571-581. https://doi.org/10.1016/0001-4575(95)00005-K

Public Authority of Civil Information (2017) "Gender by nationality and age and governorate". [online] Available at: http://stat.paci.gov.kw/ englishreports/. [Accessed: 26 January 2018]

Reason, J. Manstead, A. Stradling, S. Baxter, J., Campbell, K. (1990) "Errors and violations on the roads: a real distinction?", Ergonomics, 33(10-11), pp. 1315-1332. https://doi.org/10.1080/00140139008925335

Stephens, A., Fitzharris, M. (2016) "Validation of the driver behaviour questionnaire in a representative sample of drivers in Australia", Accident Analysis \& Prevention, 86(1), pp. 86-198. https://doi.org/10.1016/j.aap.2015.10.030

Streiner, D. L. (2003) "Starting at the beginning: An introduction to coefficient alpha and internal consistency", Journal of Personality Assessment, 80(1), pp. 99-103. https://doi.org/10.1207/S15327752JPA8001_18

Sumer, N. (2003) "Personality and behavioral predictors of traffic accidents: testing a contextual mediated model", Accident Analysis \& Prevention, 35(6), pp. 949-964. https://doi.org/10.1016/S0001-4575(02)00103-3

Underwood, G., Chapman, P., Wright ,S., Crundall D. (1999) "Anger while driving", Transportation Research Part F: Traffic Psychology and Behaviour, 2(1), pp. 55-68. https://doi.org/10.1016/S1369-8478(99)00006-6

Wang, H., Naghavi, M., Allen, C., Barber, R. M. (2016) "Global, regional, and national life expectancy, all-cause mortality, and cause-specific mortality for 249 causes of death, 1980-2015: a systematic analysis for the global burden of disease study 2015", The Lancet, 388(10053), pp. 1459-1544. https://doi.org/10.1016/S0140-6736(16)31012-1

Warrens, M. J. (2014) "On Cronbachs alpha as the mean of all possible k-split alphas", Advances in Statistics, 2014, ID 742863. https://doi.org/10.1155/2014/742863 


\section{Appendix}

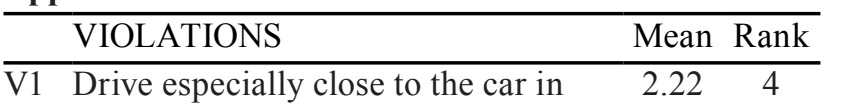

front as a signal to its driver to go

faster or get out of the way

V2 Cross a junction knowing that the traf- $0.92 \quad 9$ fic lights have already turned red

V3 Disregard the speed limits late at night $2.02 \quad 6$ or early in the morning

V4 Disregard the speed limits on a $2.09 \quad 5$ motorway

V5 Angered by a particular class of road $2.56 \quad 2$ user and indicate your hostility by whatever means you can

V6 Become impatient with a slow drive in the outer lane and overtake on the inside (right) lane

V7 Get involved with unofficial 'races' $0.82 \quad 10$ with other drivers

V8 Angered by another driver's behavior, $1.07 \quad 8$ you give chase with the intention of giving him/her a piece of your mind

V9 Sound your horn to indicate your annoyance to another road user

V10 Stay in a motorway lane that you know will be closed ahead until the last minute before forcing your way into the other lane.
E7 Under estimate the speed of an oncoming vehicle when overtaking

E8 Apply sudden brakes on a slippery 1.068 road, or steer wrong way in a skid

\begin{tabular}{llc}
\hline LAPSES & Mean & Rank \\
\hline L1 & Get into the wrong lane when & $1.84 \quad 4$
\end{tabular}
approaching a roundabout or a junction

L2 Misread the signs and exit from the $\quad 1.16 \quad 8$ roundabout on the wrong road

L3 Forget where you left your car in the $1.91 \quad 3$ car park

L4 Hit something when reversing that you $1.24 \quad 7$ had not previously seen

L5 Attempt to drive away from the traffic $2.11 \quad 1$ lights

L6 Switch on one thing, such as head- $1.27 \quad 6$ lights, when you meant to switch on something else, such as wipers

L7 Intending to drive to destination A $1.96 \quad 2$ and, you 'wake up' to find yourself in destination $\mathrm{B}$, because the latter is your more usual destination

L8 Realize you have no clear recollection $1.78 \quad 5$ of the road along which you have been travelling

\footnotetext{
ERRORS

E1 Attempt to overtake someone that you $1.30 \quad 3$

hadn't noticed to be signaling a left turn

E2 Miss 'Give Way' signs and hardly avoid colliding with traffic having right of way

E3 Fail to notice that pedestrians are crossing when turning into a side street from a main road

E4 Queuing to turn right onto a main road, you pay such close attention to the mainstream of traffic that you nearly hit the car in front

E5 On turning right nearly hit a two wheeler who has come up on your inside

E6 Fail to check your rear-view mirror before pulling out or changing lanes, etc.

\section{Mean Rank}

$1.26 \quad 4$

$1.36 \quad 2$

